\title{
Exploring the effects of cognitive destination image attributes on tourist satisfaction and destination loyalty: a case study of Málaga, Spain
}

Explorando los efectos de los atributos del destino turístico en la satisfacción y lealtad: una aplicación en Málaga, España

\author{
Vanesa F. Guzman-Parra
}

University of Málaga, Faculty of Economics and Business Science, Campus El Ejido, s/n - 29071 Málaga, Spain, vgp@uma.es

\author{
José Roberto Vila-Oblitas
}

University of Málaga, Faculty of Economics and Business Science, Campus El Ejido, s/n - 29071 Málaga, Spain, joseroberto@uma.es

\section{Francisco Javier Maqueda-Lafuente}

University of Málaga, Faculty of Economics and Business Science, Campus El Ejido, s/n - 29071 Málaga, Spain, maqueda@ehu.es

\section{Abstract}

This article has attempted to provide empirical evidence of the relationships between two groups of perceived destination image attributes, tourist satisfaction and tourist loyalty. In order to explore these relationships, two groups of destination image attributes perceived in situ have been studied: "hard ware" and "human ware" attributes of a south Spain destination. A theoretical model is tested on a sample of tourists using structural equations modeling. A positive relationship is detected between the variables. From a practical point of view, recommendations were made on the importance of destination image attributes such us "hard ware attributes" and "human ware attributes" that generate favorable word-of-mouth recommendations and revisit intentions.

Keywords: Perceived destination image, customer satisfaction, destination loyalty, corporate image, tourism.

\section{Resumen}

El presente estudio trata de explorar las relaciones entre los atributos percibidos del destino turístico, y las variables satisfacción y lealtad. Con el fin estudiar dichas relaciones dos grupos de atributos percibidos in situ en relación a la imagen del destino se han analizado ("hard ware" y "human ware"). El modelo de ecuaciones estructurales es probado en una muestra de turistas de un destino del sur de España, detectándose relación positiva entre las variables. Recomendaciones sobre la importancia de la gestión de los atributos del destino e implicaciones para el sector se comentan en las conclusiones.

Palabras clave: Imagen del destino, satisfacción, lealtad, turismo, atributos del destino.

\section{Introduction}

Several studies have studied tourist loyalty in relation to tourist satisfaction, service quality, perceived value, and destination image (Chen \& Chen, 2010; Zhang, Fu, Cai \& Lu., 2014).

The understanding of destination image could increase the predictability of tourist loyalty but destination image and tourist loyalty are multi-dimensional constructs and the impact of destination on tourist loyalty is a complex phenomenon (Zhang et al., 2014).

The purpose of this study is to present an analysis of cognitive attributes of destination image perceived in situ by tourist, studying the assessment of several "hard ware" and "human ware" attributes of a determined place of South Spain. The present paper tries to explore the theoretical and empirical evidence on the relationships between these destination image tourist attributes, tourist satisfaction and destination loyalty.

The paper is organized as follows. After a literature review, the research model is explained. The research design and data analysis are discussed next. After presenting the findings, avenues for further research are suggested.

\section{Theoretical background}

\section{Destination image}

In the current competitive environment, the destination image has become an important instrument to achieve a different positioning in relation to competitors. Agapito, Valle \& Mendes (2013) explain that purchase behavior is determined by a very high complexity of variables.

Destination image is commonly accepted as an important aspect in successful tourism development and destination marketing (Tasci \& Gartner, 2007; Agapito, Mendes \& Valle, 2010; Rey, Almeida, Miranda \& Elias-Almeida, 2012; Rey Moreno, Medina Molina \& Rufín Moreno, 2013; Agapito, Mendes \& Valle, 2014).

Numerous authors have pointed out the influence of tourism image on consumer behaviour (Baloglu, \& McCleary, 1999; Tasci \& Gartner, 2007; Agapito, Mendes \& Valle, 2013; Rey Moreno, Medina Molina, \& Rufín Moreno, 2014; Santos, Ferreira \& Costa, 2014). Literature suggests that those destinations with strong, positive images are more likely to be considered and chosen in the travel decision process (Woodside \& Lysonski, 1989).

While the definition of tourism destination image varies among scholars, it is generally defined as "an attitudinal concept consisting of the sum of beliefs, ideas and impressions that a tourist holds of a destination" (Crompton, 1979).

Multiple methods of researching destination images are used such as, factor analysis (Baloglu \& McCleary, 1999), t-tests (Chaudhary, 2000), etc. but there is not one accepted definitive research measure (Pike, 2002). Previous studies 
show that the image of a destination is a critical factor in influencing tourists' satisfaction (Loureiro \& Gonzalez, 2008).

There is no consensus about a specific definition of destination image (Jenkins, 1999). However, literature support that the study of the construct should include three components: cognitive, affective and behavioural/conative (Agapito, Valle \& Mendes, 2011; Hidalgo-Alcázar, Sicilia-Piñero \& Ruiz de Maya, 2014; San Martín \& Rodríguez del Bosque, 2008).

Several authors propose that tourist forms the cognitive image, based on which affective componets are developed and then conative image is constructed (Matos, Mendes \& Valle, 2012; Chen \& Phou, 2013; Zhang et al., 2014). Perceptual or cognitive evaluation refers to beliefs and knowledge about an object whereas affective refers to feelings about it (Zimmer \& Golden 1988).

Cognitive component refers to the beliefs a person has of the characteristics or attributes of a tourist destination (Baloglu, 1999; Pike \& Ryan, 2004), while the affective dimension is represented by the individual's feelings toward the tourist destination (Kim \& Richardson, 2003).

In this paper we are going to study cognitive image, which solicit tourists' perception on multiple attributes of the destination, such as attractions, infrastructure, environment, and service quality (Beerli \& Martín, 2004; Gallarza, Gil \& Calderón, 2002).

\section{Satisfaction}

Tourist satisfaction is relevant to successful destination marketing since it influences variables such as the choice of destination, the consumption of products and services, and the decision to return (Kozak \& Rimmington, 2000).

Destination image is an antecedent of satisfaction and satisfaction has a positive influence on destination loyalty (Geng-Qing \& Qu' 2008). Satisfaction can be used as a measure to study the product offered at the destination (Bramwell, 1998). Customer satisfaction is problematic to define and operationalize. In the present research satisfaction is measured as the answer to the following questions: "Considering all your tourist experience, how satisfied are you with your visit to Málaga?" and "To what degree did Málaga fulfill your expectations?". This approach is perhaps the most common in customer satisfaction measurement practice (Ryan \& Huyton, 2002).

\section{Loyalty to the destination}

Literature shows that customer loyalty is mediated by customer satisfaction (McAlexander, Kim \& Roberts, 2003). Customer loyalty is often measured by analyzing the intention to continue buying the same product, intention to buy more of the same product, repeat purchase and the willingness to recommend the product to others (Gronholdt, Martensen \& Kristensen, 2010; Correia \& Kastenholz' 2011; Richard \& Zhang, 2012).

Taylor (1998) stated that "likelihood to recommend a product or service to other", "likelihood to purchase a product or service again" constituted good indices of assessing customer loyalty. Chen \& Gursoy (2001) identified the concept with the level of tourists' perceptions of a destination as a recommendable place. Thus, travelers' loyalty to a destination is in this study measured by two items: "likelihood to recommend visiting Málaga to other", "likelihood to visit Málaga again".

\section{Methodology}

With the help of a questionnaire, the primary data collection was conducted and the Málaga tourists' perceptions were obtained. A total of 398 usable questionnaires were collected. The surveys have been conducted by performing face to face questionnaires during May of 2012 in strategic touristic points of Málaga (Museo Picasso, Puerto de Málaga, Catedral, etc.).

The tourists who were visiting the above locations at the time of the survey were considered to be the target population.

The model this paper proposes is based on European Customer Satisfaction Index (ECSI). It is based of the Swedish Customer Satisfaction Barometer (Fornell, 1992). Data were analyzed using SPSS 16.0 (SPSS, Inc., California) and Smart PLS was used to identify relationships among the constructs in the theoretical model (Ringle, Wende and Will 2005). Partial Least Squares (PLS) has been suggested as a method for estimating the Consumer Satisfaction Index models (Fornell, 1992). A series of hypotheses was developed and built into a 40 items questionnaire administered to 398 tourists.

ECSI model was used as a reference to measure the determinants of tourist satisfaction, and the impact that the antecedents of satisfaction has on the loyalty to the destination. The European Consumer Satisfaction Index (ECSI) is an economic indicator applicable for a number of different industries that measures customer satisfaction. Its application provides us a specific analysis of "human ware" attributes, although the model has been simplified. The proposed conceptual model of tourist satisfaction includes four latent constructs, with tourist satisfaction and tourist loyalty placed as central constructs. It incorporates two antecedent constructs: perceived value of "hard ware" attributes and perceived value of "human ware" attributes (see figure 1).

Gronholdt, Martensen \& Kristensen (2010) differentiate the following concepts regarding two groups of attributes: "hard ware", which considers the product attributes, and "human ware", which represents the associated customer interactive elements.

In order to establish a measurement scale of hard ware attributes we have selected the non-social dimensions proposed by Beerli \& Martín (2004) and other authors. The final stage of the continuum of the stages of image formation is the development of a Destination perceived image. It results from the actual experience of visiting the destination with images held previously (Prebensen, 2007).

We are going to consider this perception "in situ" in order to analyze perceived image of the destination although tourists' experience doesn't end with the trip and Destination image is open to change to different extents and in different ways (Vaughan, 2007). The relationships among tourist satisfaction and loyalty to the destination are widely studied in tourism 
research. However, the delineation between the constructs is a debated issue.

In this study, two single-item measures were used for assessing tourist destination loyalty as the ultimate dependent construct: tourists' intention to revisit Málaga and their willingness to recommend Málaga to others using a 10-point
Likert scale ranging from 1 as not at all likely to 10 as extremely likely.

Based on the above relationships suggested in the literature, a theoretical model is proposed. Table 1 shows latent variables and the different indicators of the model.

Table 1 - Latent variables and indicators of the model

\begin{tabular}{|c|c|c|}
\hline Latent variables & Indicators & Literature review \\
\hline \multirow{6}{*}{$\begin{array}{l}\text { Perceived value of } \\
\text { "hard ware" attributes }\end{array}$} & Natural resources and enviroment & Beerli \& Martin (2004); Geng-Qing \& Qu' (2008). \\
\hline & General infrastructure & Beerli \& Martin (2004); Qu, Kim \& Im (2011) \\
\hline & Tourist infrastructure & Beerli \& Martin (2004); Qu, Kim \& Im (2011) \\
\hline & Leisure and recreation tourist resources & Beerli \& Martin (2004) \\
\hline & Political an economic factors & Beerli \& Martin (2004) \\
\hline & Historical and artistical resources & Beerli \& Martin (2004)-, Geng-Qing \& Qu (2008) \\
\hline $\begin{array}{l}\text { Perceived value of } \\
\text { "human ware" } \\
\text { attributes }\end{array}$ & $\begin{array}{l}\text { Hospitality and friendliness of the local } \\
\text { residents } \\
\text { Folklore and popular culture } \\
\text { Help with language barriers } \\
\text { Personal attention received in touristic } \\
\text { establishments } \\
\text { Personal attention received in other } \\
\text { establishments. }\end{array}$ & $\begin{array}{l}\text { Kozak \& Rimmington (1998); Ritchie \& Crouch (2003); } \\
\text { Pike \& Ryan (2004)-, Gallarza et al. (2002) }\end{array}$ \\
\hline \multirow{2}{*}{ Tourist satisfaction } & $\begin{array}{l}\text { Considering your tourist experience, } \\
\text { how satisfied are you with your visit to } \\
\text { Málaga? }\end{array}$ & \multirow{2}{*}{ Ryan \& Huyton (2002); Geng-Qing \& Qu (2008) } \\
\hline & $\begin{array}{l}\text { To what degree did Málaga fulfil your } \\
\text { expectations? }\end{array}$ & \\
\hline \multirow{2}{*}{$\begin{array}{l}\text { Touris loyalty to the } \\
\text { destination }\end{array}$} & $\begin{array}{l}\text { Likelihood to recommend visiting } \\
\text { Málaga to other }\end{array}$ & \multirow{2}{*}{ Taylor (1998); Geng-Qing \& Qu (2008) } \\
\hline & Likelihood to visit Málaga again & \\
\hline
\end{tabular}

As the review of the literature shows, perceived image of the destination is expected to have a positive effect on customer satisfaction and customer loyalty. Thus, we propose the following hypothesis:

$\mathbf{H}_{\mathbf{1}}$. Perceived value of "human ware attributes" has a positive influence on tourist satisfaction.

$\mathbf{H}_{2}$. Perceived value of "hard ware attributes" has a positive influence on tourist satisfaction.

$\mathbf{H}_{3}$. Tourist satisfaction will have a positive influence on customer loyalty.

\section{Results.}

\subsection{Demographic profile}

The demographic profile of the respondents indicated that there were slightly more males (58.3 per cent) than females (41.7 per cent). Males mainly travel alone or with friends and females have a higher "family" frequency. The sample is predominantly younger. Slightly less than half $(43.0 \%)$ of the sample were aged between 30 - to 45 -years-old and $37.7 \%$ were aged between 19- to 29-years-old (table 2). Respondents were of the following nationalities: German (17.6\%), British (32.2\%), French (4.5\%), Scandinavian (17.8\%) and from another province of Spain (29.6\%).

Table 2 - Sample distribution

\begin{tabular}{|l|l|l|l|}
\hline \multicolumn{1}{|c|}{ Age } & Frequency & Percent & Valid Percent \\
\hline $18-29$ & 150 & 37.7 & 37.7 \\
\hline $30-45$ & 171 & 43.0 & 43.0 \\
\hline $46-60$ & 69 & 17.3 & 17.3 \\
\hline$>60$ & 8 & 2.0 & 2.0 \\
\hline Gender & Frequency & Percent & Valid Percent \\
\hline Male & 232 & 58.3 & 58.3 \\
\hline Female & 166 & 41.7 & 41.7 \\
\hline Travel party & Frequency & Percent & Valid Percent \\
\hline Alone & 8 & 2.0 & 2.0 \\
\hline Couple & 159 & 39.9 & 39.9 \\
\hline Family & 46 & 11.6 & 11.6 \\
\hline Friends & 185 & 46.5 & 46.5 \\
\hline Origin & Frequency & Percent & Valid Percent \\
\hline German & 70 & 17.6 & 17.6 \\
\hline British & 128 & 32.2 & 32.2 \\
\hline Scandinavian & 26 & 6.5 & 6.5 \\
\hline French & 18 & 4.5 & 4.5 \\
\hline Spanish & 118 & 29.6 & 29.6 \\
\hline Other & 38 & 9.5 & 9.5 \\
\hline
\end{tabular}




\begin{tabular}{|l|l|l|l|}
\multicolumn{1}{|c|}{ Age } & Frequency & Percent & Valid Percent \\
\hline Per-day spending average & Frequency & Percent & Valid Percent \\
\hline$<9,99 €$ & 38 & 9.5 & 9.5 \\
\hline $10-12,99 €$ & 129 & 32.4 & 32.4 \\
\hline $13-15 €$ & 132 & 33.2 & 33.2 \\
\hline$>15 €$ & 99 & 24.9 & 24.9 \\
\hline Total & 398 & 100.0 & 100.0 \\
\hline Stay & Frequency & Percent & Valid Percent \\
\hline $1-3$ days & 91 & 22.9 & 22.9 \\
\hline $4-6$ days & 87 & 21.9 & 21.9 \\
\hline 1 week & 135 & 33.9 & 33.9 \\
\hline$>1$ week & 85 & 21.4 & 21.4 \\
\hline Total & 398 & 100.0 & 100.0 \\
\hline
\end{tabular}

\subsection{Structural Equations Modeling}

PLS-model estimation was performed using the software SmartPLS (Ringle, Wende, \& Will, 2005). The item scales are comparable, so the standardization of the data is not necessary.

Average variance extracted (AVE) measures the amount of variance that a construct captures from its indicators relative to the amount due to measurement error. It is suggested that $50 \%$ or more variance of the indicators should be accounted for (AVE > 0.5). Results support this recomendations (see table 3). Composite reability is recommended to be greater $\tan 0.7$. In our research, all of the latent constructs have measures of internal consistency that exceed 0.7 .

Table 3 - Measurement results

\begin{tabular}{|c|c|c|c|}
\hline Construct & Item Loading & Composite Reliability & $\begin{array}{c}\text { Average Variance } \\
\text { Extracted (AVE) }\end{array}$ \\
\hline Perceived value of "human ware" attributes (HU) & & 0,877 & 0,594 \\
\hline HU1 Hospitality and friendliness & 0,596 & & \\
\hline HU2 Folklore and popular culture & 0,625 & & \\
\hline HU3 Help language & 0,857 & & \\
\hline HU4 Personal attention tourist establishments & 0,861 & & \\
\hline HU5 Personal attention non tourist establishments & 0,864 & & \\
\hline Perceived value of "hard ware" attributes (HA) & & 0,906 & 0,618 \\
\hline HA1 Natural Resources & 0,808 & & \\
\hline HA2 General Infrastructure & 0,801 & & \\
\hline HA3 Tourist Infrastructure & 0,842 & & \\
\hline HA4 Tourist Leisure and Recreation & 0,830 & & \\
\hline HA5 Political and Economic Factors & 0,686 & & \\
\hline HA6 Historical resources & 0,739 & & \\
\hline Satisfaction (SAT) & & 0,962 & 0,926 \\
\hline $\begin{array}{l}\text { SAT1 Considering all your tourist experience, how } \\
\text { satisfied are you with your vi }\end{array}$ & 0,960 & & \\
\hline $\begin{array}{l}\text { SAT2 To what degree did Málaga fulfill your previous } \\
\text { expectations? }\end{array}$ & 0,965 & & \\
\hline Loyalty (LOYAL) & & 0,976 & 0,953 \\
\hline LOYAL1 likelihood to recommend visiting Málaga to other & 0,978 & & \\
\hline LOYAL2 likelihood to visit Málaga again & 0,975 & & \\
\hline
\end{tabular}

Discriminant validity indicates the extent to which a given construct is dissimilar from other latent variables. The FornellLarcker-criterium can be used to judge discriminant validity
(Fornell \& Larcker (1981). All latent constructs satisfy this condition (see table 4).

Table 4 - Discriminant Validity. Fornell-Larcker Criterium

Perceived value of "human
ware" attributes (HU)
Perceived value of "hard
ware" attributes (HA)
Satisfaction (SAT)
Loyalty (LOYAL)

$\begin{gathered}\text { Perceived value of } \\ \text { "human ware" } \\ \text { attributes (HU) }\end{gathered}$
$\mathbf{0 , 7 7 1}$
0,285
0,389
0,507

0,507

$\begin{gathered}\text { Perceived value of } \\ \text { “hard ware" attributes } \\ \text { (HA) }\end{gathered}$
0,786
0,587
0,639

Satisfaction (SAT)

Loyalty (LOYAL)

0,830

0,976 
Figure 1 shows the structural model and results obtained. The first essential criterion for judging the inner model is the endogenous variables' determination coefficient $\left(R^{2}\right)$, since it measures the relationship of latent variables explained variance to its total variance (Henseler, Ringle \& Sinkovics 2009).

Figure 1 - Path model results based on analysis of data.

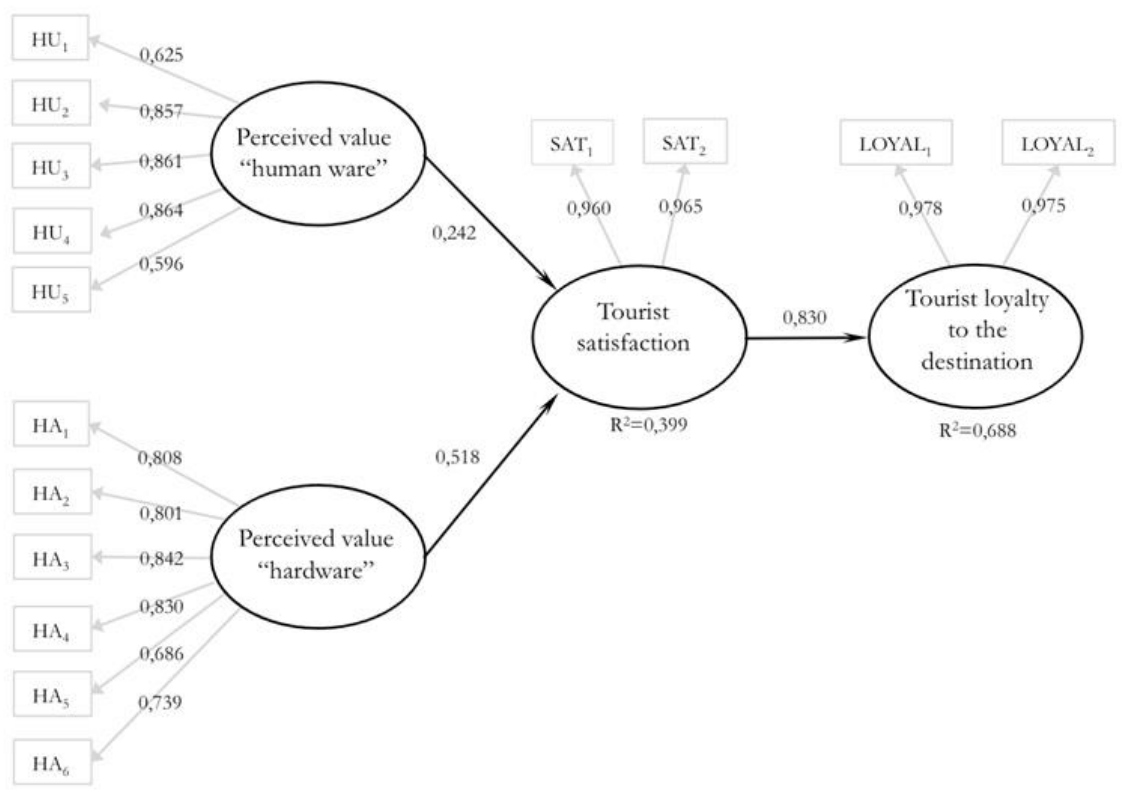

As all of the $R^{2}$ are greater than the recommended level, each path was examined to assess their level of significance. $R^{2}$ of all dependent constructs are recommended to be at least 0.33 as proposed by Chin (1998).

The structural model provided support for all of the hypothesized relationships. The stability of the estimates was tested with the bootstrap re-sampling procedure involving 500 sub-samples. We have found empirical evidence confirming these hypotheses (see table 5):
$\mathbf{H}_{1}$. Perceived value of "human ware attributes" has a positive influence on tourist satisfaction.

$\mathbf{H}_{\mathbf{2}}$. Perceived value of "hard ware attributes" has a positive influence on tourist satisfaction.

$\mathbf{H}_{\mathbf{3}}$. Tourist satisfaction will have a positive influence on customer loyalty.

Table 5 - Path coefficients and hypothesis testing

\begin{tabular}{|l|l|l|l|l|}
\hline \multicolumn{1}{|c|}{ Relationship } & \multicolumn{1}{|c|}{ Path coeficient } & \multicolumn{1}{|c|}{$\begin{array}{c}\text { T Stadistics } \\
\text { (Bootstrap) }\end{array}$} & \multicolumn{1}{|c|}{ P values $^{*}$} \\
\hline $\mathrm{H}_{1}$ & "Human ware" attributes ->Satisfaction & 0.242 & 4.761 & 0.00 \\
\hline $\mathrm{H} 2$ & "Hard ware" attributes -> Satisfaction & 0.518 & 11.284 & 0.00 \\
\hline $\mathrm{H} 3$ & Satisfaction -> Loyalty & 0.830 & 44.795 & 0.00 \\
\hline
\end{tabular}

${ }^{*} p<0.05$

\section{Discussion}

Providing tourists with memorable tourism experiences is important for achieving success in the highly competitive tourism marketplace (Kim, 2014). It is crucial to gain a better understanding of why travelers are loyal to a determined destination and what drives the loyalty, and destination marketers can potentially influence final destination choices (Oppewal, Huybers, \& Crouch, 2015).

In this study, based within the theoretical framework developed from the existing literature, relationships between the two groups of perceived destination image attributes, tourist satisfaction and loyalty have been analyzed. We have considered literature relating to tourism destination development and have attempted to understand the implications of the perception of several destination attributes in satisfaction and loyalty variables. The fragmentation of information sources and communication channels, make destination image management more complex (Llodrà-Riera et al., 2015).

Using a Partial Least Squares (PLS) structural equation modeling approach findings indicate a positive relationship between studied variables. This finding corroborates previous researches results.

The results of this study should provide scholars and practitioners working in tourist destination with new insights into the role of the attributes of destinations and their role in 
tourist loyalty. Since satisfaction affects destination loyalty, the study of these variables is essential to destination competitiveness. The special characteristics of tourism determine that many elements are involved in the formation of tourists' destination image, for example the perception of "hard ware" attributes of the destination such as natural resources and enviroment, general infrastructure, etc. to "soft ware" attributes such as hospitality and friendliness of the local residents, folklore and popular culture, etc.

Although the scale of the attributes of destinations perceived attributes was developed following a rigorous method, the study has some important limitations. For example, attribute scales for measuring destination image omit imformation, and the causal relationships revealed need to be treated with caution, since an accidental sampling is used in this study. Second, the study is restricted geographically to one region in Spain, so this limits the possibility of taking a broader view of the results and having a relatively small sample size limits the number of variables that can be included in the model.

Model modification based more on theoretical criteria is suggested. Future research could usefully investigate other variables applicable to be included in a measurement model of satisfaction and loyalty. For example, service quality, previous expectations, and perceived quality factors may be considered as potential mediating factors. Finally, the study could also be repeated in other locations in order to test for model invariance among different destinations.

In summary, this research has provided a better understanding for constructs such as the two groups of perceived destination image attributes (human ware and hard ware), customer satisfaction and customer loyalty from the tourists' perspective. The study of perceived destination image and its relationship with tourist satisfaction and tourist loyalty to de destination is crucial in terms of the implementation of the tourist destination management.

\section{References}

Agapito, D., Mendes, J. \& Valle, P. (2010). Destination image. Perspectives of tourism versus residents. European Journal of Tourism, Hospitality and Recreation. 1 (1), 90-109.

Agapito, D., Valle, P. \& Mendes, J. (2011). Understanding tourism recommendation through destination image: a chaid analysis. Tourism \& Management Studies, 33, 33-42.

Agapito, D., Valle, P. \& Mendes, J. (2013). The Cognitive-AffectiveConative Model of Destination Image: A Confirmatory Analysis. Journal of Travel \& Tourism Marketing, 30 (5), 471-481.

Agapito, D., Valle, P. \& Mendes, J. (2014). The sensory dimension of tourist experiences: Capturing meaningful sensory-informed themes in Southwest Portugal. Tourism Management, 42, 224-237.

Almeida, P., Miranda, F.J. \& Elias-Almeida, A. (2012). Aplicação da análise iportância-valor aos components da imagem de um destino turístico. Tourism \& Management Studies, 8, 65-77.

Baloglu, S. (1999). A path analytic model of visitation intention involving information sources, socio-psychological motivations, and destination image. Journal of Travel and Tourism Marketing, 8(3), 81-91.

Baloglu, S., \& McCleary, K. W. (1999). A model of destination image formation. Annals of Tourism Research, 26(4), 868-897.

Beerli, A., Martin, J. D. (2004). Factors influencing destination image, Annals of Tourism Research, 31(3), 657-681.

Bramwell, B. (1998). User satisfaction and product development in urban tourism. Tourism Management, 19(1), 35-47.
Byrne, B. M. (2001). Structural equation modeling with AMOS: Basic concepts, applications, and programming. Multivariate Applications Series, Mahwah, NJ.: Lawrence Erlbaum Associates Publishers.

Chaudhary, M. (2000). Indian's image as a tourist destination-a perspective of foreign tourists, Tourism Management. 21(3), 293-297.

Chen, C.F., \& Chen, F.S.(2010). Experience quality, perceived value, satisfaction and behavioral intentions for heritage tourists, Tourims Management, 31(1), 29-35.

Chen JS, \& Gursoy D (2001) An investigation of tourists' destination loyalty and preferences. International Journal of Contemporary Hospitality Management 13(2), 79-85

Chen, C.F. \& Phou, S. (2013). A closer look at destination: Image, personality, relationship and loyalty, Tourism Management, 36, 269-278.

Chin, W. W. (1998) 'Issues and opinion on structural equation modeling', MIS Quarterly, 22 (1), 7-16.

Correia, S.M. \& Kastenholz, E. (2011). Corporate reputation, satisfaction, delight, and loyalty towards rural lodging units in Portugal, International Journal of Hospitality Management, 30, 575-583.

Crompton, J.L. (1979). An assessment of the image of the Mexico as a vacation destination and the influence of geographical location upon the image, Journal of Travel Research. 4, 18-23.

Fornell C. (1992). A National Customer Satisfaction Barometer: The Swedish Experience., Journal of Marketing. 56, 6-21.

Fornell, C. \& Larcker, D. (1981). Evaluating structural equations models with unobservable variables and measurement error. Journal of Marketing Research, 18, 39-50.

Gallarza, M. G., Gil Saura, I., \& Calderón García, H. (2002). Destination image: towards aconceptual framework. Annals of Tourism Research, 29(1), 56-78.

Geng-Qing Chia,C. \& Qu, H. (2008). Examining the structural relationships of destination image, tourist satisfaction and destination loyalty: An integrated approach, Tourism Management, 29 (4), 624-636.

Gronholdt L., Martensen A., \& Kristensen, K. (2010). The relationship between customer satisfaction and loyalty: Cross-industry differences, Total Quality Management. 11 (4-5), 509-514.

Henseler, J., Ringle, C. M., \& Sinkovics, R. R. (2009). The use of partial least squares path modeling in international marketing. Advances in international marketing, 20, 277-319.

Hidalgo Alcázar, C., Sicilia Piñero, M. \& Ruiz de Maya, S. (2014). The effect of user-generated content on tourist behavior: the mediating role of destination image. Tourism \& Management Studies, 10, 158-164.

Jenkins, O. (1999), Understanding and measuring tourist destination images, International Journal of Tourism Research, 1, 1-15.

Kim, J. H. (2014). The antecedents of memorable tourism experiences: The development of a scale to measure the destination attributes associated with memorable experiences. Tourism management, 44, 34-45.

Kim, H., \& Richardson, S. L. (2003). Motion picture impacts on destination images. Annals of Tourism Research, 30(1), 216-237.

Kozak, M. \& Rimmington, M. (1998). Benchmarking: destination attractiveness and small hospitality business performance, International Journal of Contemporary Hospitality Management, 10 (5), 74-78.

Kozak, M., \& Rimmington, M. (2000). Tourist satisfaction with Mallorca, Spain, as an off-season holiday destination. Journal of Travel Research, 38(3), 260-269.

Loureiro, S. M., \& Gonzalez, F. J. (2008). The importance of quality, satisfaction, trust, and image in relation to rural tourist loyalty, Journal of Travel \& Tourism Marketing, 25(2), 117-136.

Llodrà-Riera, I., Martínez-Ruiz, M. P., Jiménez-Zarco, A. I., IzquierdoYusta, A., Isabel, A., \& Izquierdo-Yusta, A. (2015). A multidimensional analysis of the information sources construct and its relevance for destination image formation Isabel Llodr a. Tourism Management, 48, 319-328. http://doi.org/10.1016/j.tourman.2014.11.012

Matos, N., Mendes, J., \& Valle, P.(2012). Revisiting the destination image construct through a conceptual model. Dos Alvarves. A multidisciplinary journal, 21, 101-117

McAlexander, J.H., Kim, S.K., \& Roberts, S.D. (2003). Loyalty: The influences of satisfaction and brand community integration. Journal of Marketing Theory and Practice, 11(4), 1-11.

Oppewal, H., Huybers, T., \& Crouch, G. I. (2015). Tourist destination and experience choice: A choice experimental analysis of decision sequence effects. Tourism Management, 48(48), 467-476. 
http://doi.org/10.1016/j.tourman.2014.12.016

Prebensen, N.K. (2007). Exploring tourists' images of a distant destination, Tourism Management. 28, 747-756.

Pike, S.(2002). Destination image analysis, a review of 142 papers from 1973 to 2000. Tourism Management 23, 541-549.

Pike, S., \& Ryan, C. (2004). Destination Positioning Analysis Through a Comparison of Cognitive, Affective, and Conative Perceptions. Journal of Travel Research. 42(4), 333-342.

Qu, H., Kim, L.H. \& Im, H.H. (2011). A model of destination branding: Integrating the concepts of the branding and destination image, Tourism Management, 32 (3), 465-476.

Rey Moreno, M., Medina Molina, C. \& Rufín Moreno, R. (2013). Satisfacción, lealtad y colectivismo en destinos culturales. Tourism \& Management Studies, 9 (2), 44-49.

Rey Moreno, M., Medina Molina, C. \& Rufín Moreno, R. (2014). Tourist attractions as a moderating element in explanatory models for loyalty development. Tourism \& Management Studies, 10(1), 112-118.

Richard, J.E. \& Zhang, A. (2012). Corporate image, loyalty, and commitment in the consumer travel industry. Journal of Marketing Management, 28 (5-6), 568-593

Ritchie, J. R. B., \& Crouch, G. I. (2003). The competitive destination: A sustainable tourism perspective. Wallingford, UK: CABI Publishing.

Ringle, C. M., Wende, S \& Will, A.(2005). SmartPLS 2. Hamburg: SmartPLS, http://www.smartpls.com

Ryan, C., \& Huyton, J. (2000) Aboriginal Tourism - a linear structural relations analysisof domestic and international tourist demand, International Journal of Tourism Research (formerly Progress in Tourism and Hospitality Research) 2(1),15-30.

Santos, M., Ferreira, \& A.M., Costa, C. (2014). Influential factors in the competitiveness of mature tourism destinations. Tourism \& Management Studies, 10(1), 73-81

San Martin, H., \& Rodriguez del Bosque, I. A. (2008). Exploring the cognitive eaffective nature of destination image and the role of psychological factors in its formation. Tourism Management, 29(2), 263-277.

Tasci, A.D.A. \& Gartner, W.C. (2007). Destination Image and Its Functional Relationships. Journal of Travel Research, 45, 413 -425.

Taylor, T. (1998). Better loyalty measurement leads to business solutions. Marketing News, 32 (22), 41-42.

Vaughan, R.D. (2007). Images of Romania as a potential holiday destination, International Journal of Tourism Policy, 1 (1), 1-16.

Woodside, A.G., \& Lysonski, S. (1989). A general model of traveller destination choice. Journal of Travel Research, 17 (4), 8-14.

Zhang, H., Fu, X., Cai, L.A., \& Lu, L. (2014). Destination image and tourist loyalty: A meta-analysis, Tourism Management, 40, 213-240.

Zimmer, M.R., \& Golden, L.L. (1988). Impressions of retail stores: A content analysis of consumer images, Journal of Retailing, 64(3), 265-293.

\section{Article history:}

Submitted: 08.07.2015

Received in revised form: 21.01.2016

Accepted: 22.01.2016 